\title{
Men in transit: the spectrum of masculinity in Caio Fernando Abreu's White Limit (1970)
}

\author{
Juan Filipe Stacul ${ }^{1}$ \\ Gracia Regina Gonçalves ${ }^{2}$
}

Caio Fernando Abreu has been seen as a paradigmatic writer for a generation which lived through turbulent transformations, especially in regards to the transition from dictatorship to democracy. At the same time, he is tied to the emergence of a countercultural movement in Brazil and to the representative movements of the seventies, associated to the acquisition of individual rights ${ }^{3}$. In this context, his literature, marked by a transgressing character, surfaces and slices through the portrait of a nuclear model of family, proposing a rupture in the ruling of the ideological constructs of the petty bourgeois in southern Brazil.

Generally speaking, the impossibility of adapting the individual to parameters that were socially established for him becomes evident in Abreu's literary creation. With that in mind as starting point, the barriers that enveloped such individual are dismantled in face of the fluid new forms of constructing identity, ratifying the image of the "spectrum" which we here adopt. This metaphor intends to reinforce the idea of non-definitude contained in the title of the romance White Limit (orig. title: Limite Branco, 1970), chosen as the object of our research.

\footnotetext{
${ }^{1}$ É graduado em Letras pela Faculdade Castelo Branco (2009), mestre em Letras - Estudos Literários pela Universidade Federal de Viçosa (2012) e doutorando em Letras - Literaturas de Língua Portuguesa pela Pontifícia Universidade Católica de Minas Gerais (PUC Minas).

${ }^{2}$ Possui graduação em Letras (1985) e em Arquitetura pela Universidade Federal de Minas Gerais (1976), mestrado pela University of North Carolina (1988) e doutorado em Letras Estudos Literários pela Universidade Federal de Minas Gerais (2001). Atualmente é Professora Associada II da Universidade Federal de Viçosa.

${ }^{3}$ To learn more about this specific moment of Brazilian history and culture, we recommend the work of Dunn (2001).
}

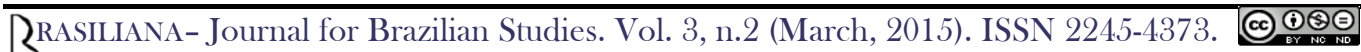


About the work in question, it is appropriate to highlight that it is an inaugural text, carrying within itself the seeds of an innovative and singular aesthetic. We believe that the "limit" mentioned in the title paradoxically suggests, rather than an idea of order or stability, multiple forms of conceiving the individual, going beyond an essentialist notion of values. In consonance with this vision, it comes to mind that white itself is, before all, spectral: crossed by light, it gives way to other colors, generating profusion, mixture and dynamicity. In an analogous manner, the individual, starting from his instability and richness, shows himself to be more special for what is or isn't seen, or cannot, at first, be perceived.

The novel in question tells the story of Maurício, the youngest son of a wealthy farming family in southern Brazil, who is seen in constant conflict with the family values and models of gender and sexuality imposed on him. During a journey of selfknowledge and discovery of the world of sexuality and love, Maurício discovers that there is no space for his subjectivity in the family environment and he needs to leave for a new experience if he want to find his place in the world. Structurally, Abreu merges Maurício's discoveries with pages of his diary, which guarantees to the reader a panoramic view of the conflicts surrounding the protagonist.

In this article, specifically, our central objective is to establish a reading that allies the constitution of subjectivity to gender relations in the narrative as interdependent forms that are also susceptible to ideological traps. Such awareness of the dangers implied in any stagnated positions regarding the subject, we would like to think of the individual as going through a recurrent learning process in parallel fashion to the critical perspective of the protagonist in the narrative. A text that is in itself subversive and ironic appears as a new proposition of an aesthetic, literary, and social character. 
Regarding the contextualization of Abreu's literary production with the social and political movement in which it is inserted, between the decades of 1970 and 1990, some relevant considerations arise. Flora Sussekind (1985), Fernando Arenas (2003), Jaime Ginzburg (2007), among others, have observed the creation of the author evolving from the debates about dictatorial governments and the literature produced after 1964, as well as the arising of a gay culture and the fight against the HIV virus - constant themes in the aforementioned historical periods.

In order to discuss specifically the relevance of Abreu's work, the Brazilian researcher Flora Sussekind takes as example the short story Garopaba mon amour, published in Stones of Calcutta (Pedras de Calcutá, 1977). In this text, the traces of writing styles, which highlight a dictatorial reality from an unveiled, journalistic-like account, comes to light. In Sussekind's words,

In Caio Fernando Abreu's short story, torture and delirium mix, forcing the narrative itself to change to accommodate them. Short paragraphs, painful descriptions intermixed with agreeable memories, accompany this subtle dialogue in which there mingle the speech of torturer and tortured, revolt and almost cinematographic account. (Sussekind, 1985, p. 47)

In this aspect, Abreu's literature would be responsible for a social critique that goes beyond factual description to be constituted in itself as a sensory literary approach, which reveals what is behind torture (feelings, digressions and personal experiences of the tortured individual) in a way both realistic and delirious. Thus, the difference between Abreu's work and other literary compositions is not only in the typicality of the 
narrated facts, but in the way in which they are executed on the page. The author reaches a type of writing that is constructed in the possibility of describing a personal experience that is not based on common-sense, but in a sensorial plunge. In this case, there is a somewhat common approach towards a victimizing positioning, recurrent among criticism on Clarice Lispector: through the same process utilized by Lispector in Mineirinho, Abreu puts himself in the place of the one hit by horror, as though he had had personally lived through the experience of torture.

According to Sussekind, this form of narration draws the act of writing closer to the writer himself. It is as though certain barriers were broken so that a more intense, visceral literature, with a self that narrates very closely to whom is narrated, is established. However, for Albuquerque, author of Tentative transgressions: homosexuality, AIDS, and the theater in Brazil (2004), "by the early to mid-1990s, the staging of plays by Caio Fernando Abreu (1948-1996) and others facilitated the presentation of unorthodox lifestyles and sexual liaisons in more matter-of-fact ways." (Albuquerque, 2004, p. 35). Regarding the importance of these theatrical pieces to the changes brought about by the political and social movements of the time, the author further elaborates:

With the onset of AIDS in Brazil in the mid-1980s the game changed entirely; for the rest of the decade and through most of the 1990s the crisis at the center of gay life also became the main focus of gayaccented theater in Brazil. The theater of Caio Fernando Abreu and others has helped to cast light on how a peripheral society dominated by inequity and violence represents its confrontations with difference. (Albuquerque, 2004, p. xi) 
In what regards the structuring of the novel, we verified that Abreu makes use of the Bildungsroman. The main characteristic in this kind of work, as the name suggests, is the formative process of the adolescent individual, which may, within certain determined and specific pedagogic molds, constitute itself under the orientation of an elder educator or mentor (Schwantes, 2007, p. 55).

In this aspect, Barbosa (2008) also recognizes White Limit (1970) as a Bildungsroman and proposes a brief analysis of the elements that make up the protagonist's learning process in the narrative. In addition, he states that Maurício's subjectivity is constructed by the "mirroring of a narrator's developing personality, [...] which in itself already adheres to the novel as the expression of an experience" (Barbosa, 2008 p. 367).

From this notion of an experience, becomes evident that the role of microuniverse space surrounding the protagonist Maurício is an important element of a selflearning process. In Barbosa's words, it is important to perceive the "symbols of the city" as the components of the subject's identity. On this track, we can place the central landmark of formation in two specific moments that mark the transition from childhood to adulthood:

In this first novel, we are surprised with Caio transferring to his narrator, the post-adolescent Maurício, his subjectivity built simultaneously to the way he observes life, family relationships and his own reality/experience. In the first part of the novel, Maurício lives in his hometown with toys in the backyard of his home and build their lonely fictions about the world around, through Drummond and Robinson Crusoe. In the second part, he is living in a big city, and little 
by little, Abreu reveals his own Porto Alegre, where he had been sent by their parents to complete secondary school. (Barbosa, 2008, p. 367)

From Barbosa's perspective, the formation process is evident not only when the transition occurs to the big city, but also at times when there is a loss of some characters in the narrative. In this respect, the absence is brought as an element of utmost importance, since the passage from adolescence to adulthood is up from symbolic deaths.

In summary, the characterization of this initial production by Caio Fernando Abreu is marked by a subversive aspect detected in the process of the main character's formation. This individual is constructed around the alienation of the young Mauricio in relation to his family, directing him out of the walls of the residence. In this aspect, we have verified that subjectivity is intimately tied to the presented spaces. We apprehend, thus, that the learning process and construction of gender is overreached by instabilities, throwing itself in a discovery of transgressive possibilities in the institutional bases.

In such discussions, the propositions of men's studies become productive. An example of these studies would be the theorizations of Elisabeth Badinter. In her work XY: On Masculine Identity (1993), the author points out that masculine identity would be associated to three moments of identification starting from the opposite viewpoints regarding the other sex: firstly, when separated from the maternal image, when the male individual concludes that he is no longer a baby; secondly, when placed in front of a child of the opposite sex, with the realization, "I am not a girl"; and, thirdly, associated to sexuality, when the individual inserts himself in the universe of male domination and verifies that he is not a homosexual. Being dominated, then, be it by the maternal figure, 
be it by another woman, or by another man, represents a rupture with "true masculinity". Badinter states:

Masculine identity is associated to the act of possessing, taking, penetrating, dominating and self-affirmation, if necessary by force. Feminine identity is associate to the act of being possessed, docile, passive, submissive. "Normality" and sexual identity are inscribed in the context of the domination of the woman by the man. Within this optic, homosexuality, which implies the domination of man by another man, is considered, if not a mental disease, at least a disturbance of gender identity. (Badinter, 1993, p.99)

What we verify, currently, is that the biggest of limits being made relative by debates around masculinity is the binary relation that is diffused not only in the literary universe, but in the construction of media discourse itself and in the most diverse discursive forms present in common sense. After all, if the individual is constituted in language, it is in it that the possibilities of both maintenance and subversion of such ideological/cultural conceptions is instituted.

This notion proposed by Badinter calls to our attention not only the ideological perils linked to the dominating male model, but also the public policies that establish social practices in gender relations. In proposing a rupture of the binary systems connected to gender technology, Badinter brings about another question that is constantly asked by studies related to the universe of the masculine: the notion of new conceptions of masculine as a conceptual milestone and practical policy for the definition of new paths in the relations that involve the social actors. 
Such questions brought by Badinter (1993) are also discussed by Nolasco (1995). According to him, this destabilization of the masculine universe in face of the "demands" of the insertion of women into the public sphere, as well as the weight of the constructions of common sense about men, have evidenced the conception of a new man; or, as preferred by the theoreticians of men's studies, multiple forms of being a man. The notion of a wide range of possibilities in the construction and representation of masculinities is what allows us to comprehend the forms of subversion in the normative structures and the "performance ability" of masculine roles.

Socrates Nolasco, in what refers to such notion, argues that "currently, it is possible to be a man without being 'macho' and oppressive", once that "the individual reveals himself perpetually dislocated in relation to his sexual body" (Nolasco, 1995, p. 7). In this fashion, we retake a notion of gender that is detached from sex, establishing an even wider panorama of masculinities. As an analysis operator, the multiple masculinities open the doors to the perception of relations, which the stagnated notion of gender did not permit, evidencing that the masculine, just as aforementioned in relation to the feminine, allows literary representations that go far beyond the description of physical and psychological attributes, aiming towards the problem of "becoming", much more so than that of "being", man.

In the process of construction of masculinities, as pointed out by Nolasco, a multiple of web of vigilance is instituted. The concept of a spatial and temporal control of the bodies, already surfaced in our discussions, also comes into play regarding masculinities. When no longer seen as the natural center of discourse, when dislocated from the comfortable position of leadership, the man becomes aware that power is not an inherent attribute, but constructed since childhood. In this manner, the perception of a framework in crisis occurs: becoming a "man" is a process more complex than 
previously imagined. In the case of sexual orientation, the question is even more problematic. In the words of Nolasco, "a boy lives under continuous vigilance, so that he may not know how determined he is in relation to his choice". (Nolasco, 1995, p. 18)

Regarding the notions of gender as spatially situated and also related to a movement of transition, it strikes us how the scene in which Mauricio experiences rituals of a homosocial universe are attached to the traditional view of masculinity, discussed in the theorizations of Badinter (1993) and Nolasco (1995). It is a passage form chapter X, The Voyage, in which the young man faces a group of men, formed by his father and his friends. In this aspect, the chapter in itself already constantly evidences the movement of transition, marked by the departure of the family towards the city, and presenting, with it, a new process of discovery for the protagonist.

The first image we observe is of Mauricio seated in the train, next to his mother, monotonously contemplating the landscape going by the window. In this moment, he observes the passage of time contemplatively, without worrying at first, with the meaning of certain relations that are built up inside the wagon. However, when he observes his surroundings with greater clarity, he becomes aware that there are no men in that space, something that leaves him rather confused. The curiosity of the young man, awakened by this verification, turns into questioning:

"Mom, where are the men, huh? There are only women here".

His mother stopped the knitting and looked at him.

"They are in the dining car", said.

Dining car - again the magic word. What men do there? Drink beer? Play cards? Use that vocabulary with terms that he did not understand? Government, president, election, knavery. And there were other words, 
more mysterious, softly spoken, underlined by weird laughter. (Abreu, 2007, p. 96)

We perceive that the notion presented here is that of someone who, starting from a delineated outlook regarding his surrounding becomes aware for the first time of the division of gender roles in specific spaces, outside of the family environment. This will put in evidence a multiple web of significations, unfolded for that young man in relation to a world of rituals, marked by specific words, and secrets that only men seemed to know. The activities inherent to the male model, in the same way, become evident: in one wagon the women knit and take care of the children, it is a silent plane, almost a situation of confinement. In the other, there is the bar, a public space, where the men drink and talk. It is there, for Mauricio, that the mystery of the unknown resides.

It is interesting to note that, in deciding to go to the men's car, Mauricio lies to his mother, saying he has to go to the bathroom. It is as though he already perceived the transgressive nature of this act, the impossibility to transit between the two environments freely. The spaces destined for each gender become more and more marked by the opposition between the descriptions of where the women and where the men stay. On the way to see his father, Mauricio's expectations draw for him images of that unknown space, with specific codes.

For Cortés, author of Spatial Policies (Políticas do Espaço, 2008), the masculine domain is constantly reaffirmed by the construction of socializing places between individuals. Therefore, the masculine is verified as neutral and natural, instituting social relations coming from architectonic phallocentrism towards the instauration of corporal practices, subjective as well as collective. In this aspect, the reiteration of the spherical 
divisions is more than a social practice, but also part of a process of power relations that infiltrates the architecture of cities, staunching through streets and buildings, until it seeps into the crevices of doors and enters the home: the panoptical is urban, but also a domestic construct.

It is starting from this notion of architecture as a place of social construction of gender relations that Cortés will elaborate the idea of the body as architecture. Rather, the dynamic relation between the spaces that constitute the individual relate intimately with a construction of the body as the materialization of movement. In this sense, the body is an architectonic significant, a building - the possibility of a place where gender might live. In other words, "the body is the place where the individual is located, where a frontier is established between the self and the other, both in the personal and physical sense, something fundamental for the construction of the social space" (Cortes, 2008, p. 126)

The relations between gender and space presented by Cortés can be seen in Abreu's novel. In this scene, especially, the opening of the wagon's door is presented as an entrance into new lands waiting to be discovered. The idea of the male model to which Mauricio should belong is presented in very caricature-like fashion:

Then he opened the other door and saw the large balcony with a glass full of unknown delights, round stools, tables and men smoking cigarettes, with their long nails in the little, their gold teeth, their strange vocabulary, hoarse whispers. For a moment, he felt lost in those smells and different shapes of the dining car. (Abreu, 2007, p. 98) 
The description of the masculine space is marked by sensorial representations. The forms which are projected in the narrative are responsible for constituting an ambient in which being a man is comprehended as a flag to be raised with its symbols and significations, not as a subjective construction, but as a representation of social demands. The presence of the young man there, thus, remotes to a social ideal in which the father instructs the son to "drink and smoke (symbols of virility), until he feels sick. He is constantly disapproved for the lack of virility: he is too much his mother's son and too little his father's". (Badinter, 1993, p. 79). It is in this aspect that Mauricio notices his greatest estrangement, i.e., the non-comprehension of such rituals that build "masculinity" and in the distancing of such in relation to his own form of constituting identity.

In the moment that he perceives himself lost amidst a series of rituals responsible for the representation of a masculine ethos, Mauricio approaches the discoveries about that universe of mysteries that he foresaw in the lake scene. Ethos, in this sense, is comprehended as that which determines the creation of ties and belonging not in that environment. In other words, "a culturally homogenized group that produces and organizes emotions shared by a certain group, with its particulars and characteristics." (Batista, 2005, p. 11)

The heteronormative direction is clearly evident, already pointing to a "gendered" construction that aims to delimitate the social role of the apprentice in that world of adult men. In respect to this process, Badinter claims that "the common objective of these rites is to change the stature of identity of the boy so that he is reborn a man $[\ldots]$ for better or for worse, once the obstacles are beaten, a transmutation occurs: boys feel themselves to be men." (Badinter, 1993, p. 71) 
Disconcerting and problematic, however, the contact that Mauricio has with other men only further evidences the dislocating character of the archetypal construction of a normative masculinity:

He poked his father and everyone was watching him in a way that made him feel even more confused.

"Your kid is pretty, but skinny". The callused hand down to the boy's legs.

"And silent too. Look at him. He said nothing".

"It's the age!" His father said. "He's very quiet even".

"It's not the age! In his age I had already mastered all the mares in the city. Be careful, huh, or he turns a sissy.

"Nah, Barbosa. It's nothing! He just likes to walk alone and read. (Abreu, 2007, p. 99)

Mauricio's first rite of initiation into the masculine universe (where he should be integrated), then, appears to be problematic. The boy feels alienated amidst the words that remote to the experiences that do not fit into a perspective of the way he sees his own existence. This alienation of the character, more than pointing to the multiple forms of "masculinity" (Machado, 2005, p. 196), also makes reference to Mauricio's insertion in an adult world that is dissonant from the patterns demanded by the family's structure.

The masculine gender constructed in the narrative, discordant from a heteronormative model, from Mauricio's insertion in spaces traditionally destined to the female microcosm, evidenced in the novel's start, to the alienation of the boy in face of the group of men's demands during the train trip, raise questions concerning 
masculinities, associated to the notions of the apprentice who sees himself in what would, or not, be the final moment of his process of "un-learning".

What can be verified, then, from Mauricio's alienation regarding the construction ritual of an archetypal masculine subjectivity, is the blurring of the frontiers guiding this framed meaning of the individual. When he sees himself in front of his father's friends, defenseless, serving as object of their normative gazes, Mauricio notices that there is a very great distance between the form demanded from a masculine model and the way he sees himself in these hegemonic constructions.

In this aspect, even though it precedes the theorizations regarding multiple masculinities, evidenced in the previous chapter, Abreu's novel already gives nuances of these questionings, starting from a dislocation of the main character in face of what was then comprehended as masculine.

The rite of passage into the masculine universe, inside the patriarchal modes, sounds contradictory as it tries to engender identity constitutions in a different way from the norm. It represents, with that, the failings of a model of materialization of gender into a sole constitution - and that is perceived very clearly in the excerpt in question.

What we have perceived, in all cases, is that the novel follows a principle of undefinition. Mauricio, even as an adult, has not yet discovered the totality of his subjectivity, and neither what, to himself, it means to be a man - once his way of living masculinity presents itself differently from the one that was presented to him institutionally.

The narrative is not closed because subjectivity is also not enclosed in specific moments. There is no ritual of transitioning into a complete man, as wanted by the traditional heteronormative model. On the other hand, there are possibilities, 
experiences, and incompletion. This open and fragmentary character of the construction of the individual and masculinity is evidenced in the novel's last chapter, Time of silence; it is, in reality, a continuation of the first chapter, from the exact moment in which it ended, marking a cyclic return to the beginning.

With this return, Abreu points towards the possibilities that are always sketching themselves, being unfolded before the individual. At a certain moment, Mauricio concludes that "it is necessary to organize the idea: take it beyond the limits of thought, rip it only from the paper and make it a part of myself, decision etched in the body." (Abreu, 2007, p. 167). Thus, the novel's closure points not to the end of apprenticeship, but towards an opening of thought, of bodily experiences, of a learning experience marked by what is in constant change.

\section{References}

Abreu, C. F. (2007). Limite Branco. Rio de Janeiro: Agir.

Albuquerque, S. J. M. (2004). Tentative transgressions: homosexuality, AIDS, and the theater in Brazil. University of Wisconsin Press.

Arenas, F. (2003). Utopias of otherness: Nationhood and subjectivity in Portugal and Brazil. Minneapolis: University of Minnesota Press.

Badinter, E. (1993). XY: On Male Identity. Columbia University Press.

Balderston, D.; Gonzalez, M. (2004). Encyclopedia of Latin American and Caribbean Literature. New York: Routledge.

Barbosa, N. L. (2008). "Infinitivamente pessoal": A autoficção de Caio Fernando Abreu, o "biógrafo da emoção". São Paulo: USP. 
Batista, A. B. (2005). Caserna - Lugar de "homens": Um olhar de gênero na formação do jovem militar. Viçosa: UFV.

Butler, J. (1993). Bodies that matter: on the discursive limits of "sex". New York: RoutLedge.

Cortés, J. M. (2008). Políticas do espaço: Arquitetura, gênero e controle social. São Paulo: Senac.

Dunn, C. (2001). Brutality Garden: Tropicalia and the Emergence of a Brazilian Counterculture. The University of North Carolina Press.

Foucault, M. (1988). História da Sexualidade I: A vontade de saber. 7. Ed. Rio de Janeiro: Graal.

Ginzburg, J. (2007). Memória da ditadura em Caio Fernando Abreu e Luís Fernando Veríssimo. O eixo e a roda. v. 15. p. 43-54.

. (2001). Escritas da tortura. Diálogos Latinoamericanos: n. 3. p. 131-146.

Maas, W. P. (2000). O cânone mínimo: o Bildungsroman na história da literatura. São Paulo: Editora UNESP.

Machado, V. (2005). As várias dimensões do masculino: traçando itinerários possíveis. Florianópolis: Estudos Feministas.

Mazzari, M. (2003). O Bildungsroman na Literatura Brasileira: prolegômenos para um estudo. São Paulo: EDUSP.

Nolasco, S. (1995). A desconstrução do masculino. Rio de Janeiro: Rocco.

Schwantes, C. (2007). Narrativas de formação contemporânea: uma questão de gênero. Estudos de Literatura Brasileira Contemporânea, nํ30. p. 53-62.

Sussekind, F. (1985). Literatura e vida literária: Polêmicas, diários e retratos. Rio de Janeiro: Zahar. 